\title{
Early childhood fat tissue changes - future risk for metabolic related diseases: subcutaneous and visceral fat adipose tissue CD163+ cells expression and collagen deposition in young male children
}

\author{
(D)Robert Mujkićc*, \\ (DD)Darija Šnajder \\ Mujkić ${ }^{2,3}$, \\ (D) Ivana Ilić' , \\ (D)Anđela Grgić' \\ DEdi Rođak², \\ DDalibor Divković ${ }^{2,3}$, \\ DKristina Selthofer- \\ Relatićn ${ }^{2,3}$ \\ 'University Josip Juraj \\ Strossmayer Osijek, Faculty \\ of Dental Medicine and \\ Health Osijek, Osijek, Croatia \\ ${ }^{2}$ University Josip Juraj \\ Strossmayer Osijek, Faculty \\ of Medicine, Osijek, Croatia \\ University Hospital Centre \\ Osijek, Osijek, Croatia
}

KEYWORDS: CD163+, childhood obesity, collagen deposit, fat tissue, insulin resistance. CITATION: Cardiol Croat. 2021;16(1-2):57. | https://doi.org/10.15836/ccar2021.57

*ADDRESS FOR CORRESPONDENCE: Robert Mujkić, Fakultet za dentalnu medicinu i zdravstvo 0sijek, Crkvena 21, HR-31000 0sijek, Croatia. / Phone: +385-98-268-113 / E-mail: robert.mujkic@gmail.com

ORCID: Robert Mujkić, https://orcid.org/0000-0002-8799-521X· Darija Šnajder Mujkić, https://orcid.org/0000-0001-7601-6509 Ivana llić, https://orcid.org/0000-0003-0952-6685 • Anđela Grgić, https://orcid.org/0000-0003-4397-0560 Edi Rođak, https://orcid.org/0000-0001-7814-2031 • Dalibor Divković, https://orcid.org/0000-0002-4269-6881 Kristina Selthofer-Relatić, https://orcid.org/0000-0002-9890-6489

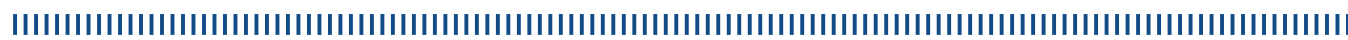

Introduction: Extracellular matrix (ECM) is essential for adipogenesis, adipose tissue growth and architecture. ECM processes are deregulated in obesity, related to immune cell accumulation in adipose tissue and impaired metabolic functions. Soluble CD163 is a new macrophage-specific serum marker elevated in inflammatory and related with obesity and diabetes mellitus II, called obesity-related insulin resistance. ${ }^{1-3}$ The study aimed to investigate the occurrence of collagen deposition and CD163+ accumulation in the subcutaneous (SAT) and visceral (VAT) adipose tissue of male children.

Patients and Methods: This research included 30 young male children, age in range 3.88 [3.10-9.71] years old, hospitalized for elective abdominal surgery at the Department of Pediatric Surgery of the University Hospital Osijek, divided into two groups depending on their body mass index score (BMI) Z-score: normal weight (NW) group, ( $\mathrm{N}=13$ ) and overweight/obese $(\mathrm{OO})$ group, (N=17). SAT and VAT samples were gained during the surgical procedure. Before the beginning of the research, patients' parent gave written consent. Immunohistochemistry for CD163+ cells was performed, and the number of positive cells was counted per $\mathrm{mm}^{2}$ of adipose tissue. Histological staining for extracellular components with standard Masson's trichrome stain method was also performed and histomorphometric analysis was conducted using the free online image analysis program Fiji, a distribution of ImageJ.

Results: The 00 group were significantly older (5.75[3.65-10.30] vs. 3.20[2.40-4.25] years old; $\mathrm{p}=0.025)$ and they had higher BMI, Z-score, waist and hip circumference. In the group of 00 , there was an increased collagen deposition in SAT compared to NW group (5.54 vs 3.89\%; $\mathrm{p}=0.048$ ). In the same 00 group, a larger adipocyte surface area in SAT when compared with NW group was observed (980.47 vs $\left.604.77 \mu \mathrm{m}^{2} ; \mathrm{p}<0.001\right)$. In VAT more CD163+ cells were counted in the group of OO children (178.00 vs 93.00; $\mathrm{p}<0,001)$

Conclusion: In healthy young male children increased collagen deposition and adipocyte hypertrophy is related to their weight status. Independent of age, more accumulation of CD163+ cells was observed in VAT of overweight/obese children. Early childhood fat tissue changes can present a future adult risk for metabolic-related diseases.
RECEIVED:

December 5, 2020

ACCEPTED:

December 18, 2020

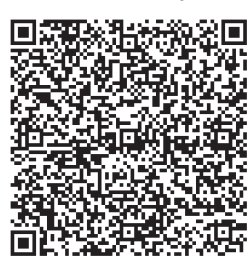

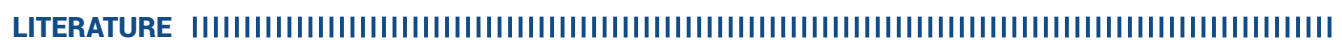

1. Tam CS, Tordjman J, Divoux A, Baur LA, Clément K. Adipose tissue remodeling in children: the link between collagen deposition and age-related adipocyte growth. J Clin Endocrinol Metab. 2012 Apr;97(4):1320-7. https://doi.org/10.1210/jc.2011-2806

2. Fjeldborg K, Christiansen T, Bennetzen M, J Møller H, Pedersen SB, Richelsen B. The macrophage-specific serum marker, soluble CD163, is increased in obesity and reduced after dietary-induced weight loss. Obesity (Silver Spring). 2013 Dec;21(12):2437-43. https://doi.org/10.1002/oby.20376

3. Mujkić R, Šnajder Mujkić D, llić l, Grgić A, Rođak E, Selthofer Relatić K, et al. EP-220 | Expression of CD163+ cells and collagen deposition in subcutaneous and visceral adipose tissue of young male children. Obesity Reviews. 2020;21(S1):126-127. 